\title{
Sources of Synergy Realization in Mergers and Acquisitions: Empirical Evidence from Non-Serial Acquirers in Europe
}

\author{
Nancy Huyghebaert ${ }^{1} \&$ Mathieu Luypaert ${ }^{2}$ \\ ${ }^{1} \mathrm{KU}$ Leuven, Belgium \\ ${ }^{2}$ Vlerick Business School, Ghent, Belgium \\ Correspondence: Mathieu Luypaert, Vlerick Business School, Reep 1, 9000, Ghent, Belgium. Tel: 32-16-248-824. \\ E-mail: mathieu.luypaert@vlerick.com
}

Received: February 27, 2013

Accepted: March 24, 2013

Online Published: April 8, 2013

doi:10.5430/ijfr.v4n2p49

URL: http://dx.doi.org/10.5430/ijfr.v4n2p49

\begin{abstract}
We empirically investigate the sources, magnitude, and timing of synergy realization for 293 M\&As by non-serial listed acquirers in Europe during 1997-2005. In contrast to much of the existing literature, we find that the shareholders of non-serial acquirers gain significantly upon deal announcement. Next, we unravel the various sources of M\&A value creation, in particular operating synergies resulting either from revenue enhancement or from savings on operating costs and investments, and financial synergies. Compared to its non-combining industry peers, the median combined sample firm reports a $4.92 \%$ larger sales growth rate by the third post-deal year. Operating costs relative to sales are reduced by an extra $1.53 \%$ over this same window. In leverage-increasing acquisitions, the median combined firm realizes a persistent $6.09 \%$ rise in its long-term debt ratio. Finally, our multivariate regression results point out that non-serial acquirers with a larger market-to-book ratio achieve more extensive operating synergies.
\end{abstract}

Keywords: mergers, acquisitions, operating synergies, financial synergies, event study

\section{Introduction}

The last decade has featured the most intense period of M\&A activity ever. Moreover, while takeovers used to be popular particularly in the USA, the M\&A waves of the 1990s and mid-2000s have turned out to be worldwide phenomena, with many deals originating in Asia and especially also in Europe (see Martynova and Renneboog, 2008; Huyghebaert and Luypaert, 2010). However, research on takeovers, typically relying on data from earlier waves, has pointed out that many acquisitions are often unable to meet the great expectations expressed at their notification. For example, Agrawal et al. (1992) report that investors in US acquiring companies in the period 1955-1987 endured a significant average loss of $10 \%$ in shareholder value in the five years following the deal. These results have been confirmed by later studies examining M\&As in the USA as well as in the UK (e.g., Gregory, 1997; Bouwman et al., 2009). Other studies have provided evidence of a detrimental impact of M\&As on accounting performance (e.g., Ravenscraft and Scherer, 1987; Dickerson et al., 1997). In a more recent study of M\&As initiated by listed acquirers in Europe, Craninckx and Huyghebaert (2011) analyze the combined firm's stock and accounting performance two, three, and five years after deal completion. They point out M\&A failure rates up to $50 \%$, which remain rather stable as of the second post-deal year. Also, M\&A failure rates do not seem to depend upon whether the target firm is publicly listed or privately held.

In spite of these high failure rates, managers still refer massively to expected synergy gains to motivate their acquisitions and to justify the premium paid for target control (e.g., Mukherjee et al., 2004; Ficery et al., 2007). In this article, we therefore wish to investigate whether and how synergies are actually realized for a sample of recent acquisitions in Europe. We follow the combining companies in our sample over a three-year post-deal window, in order to identify the various sources of operating as well as financial synergies. Operating synergies refer to the gains that result from merging the operations of two firms, and can be classified into revenue-based, cost-based, and investment-based synergies. Financial synergies arise when the combined firm can increase its debt ratio following the deal, which could allow realizing tax savings and reducing the cost of capital. In order to calculate measures of operating and financial synergies for each transaction in our sample, we need to identify a clean post-M\&A window in which acquirers did not engage in any other takeover(s). As a consequence, the focus of our study is inevitably on 
non-serial acquirers. This could result in more positive findings on M\&A value creation as compared with previous studies. Laamanen and Keil (2008) indeed find that US firms that frequently engage in M\&As, so-called serial acquirers, exhibit significantly worse three-year abnormal stock returns than non-serial acquirers. Poor M\&A performance has been commonly associated with managerial agency problems, overconfidence, and hubris, which may all incite managers to pursue excessive, non-value-maximizing firm growth (see also Billet and Qian, 2008; Ismail, 2008). Nonetheless, as a number of recent articles explicitly selected those serial acquirers as study object, while no research to date has focused on the subgroup of non-frequent acquirers, we consider our study as complementary to this prior research. Moreover, in comparison with the USA, serial acquisitions occur less frequently in Europe (Craninckx and Huyghebaert, 2011).

Our study contributes to the current literature in several ways. First of all, while most research up till now has evaluated M\&A performance by examining abnormal stock returns or accounting profitability over a specific post-deal window, we embrace a more comprehensive approach by disentangling the various sources of synergistic gains. A number of prior studies did explore in detail the sources of M\&A value creation, by relying on case surveys or on forecasts from managers and financial analysts. (Note 1) Yet, those studies may have suffered from a sample selection bias when the management discloses precise synergy forecasts only when they expect those synergies to be substantial. In contrast, we aim to measure actually realized synergies by analyzing the financial statements of the combining companies and their non-combining industry peers before and after deal completion. In addition, we investigate the timing of realizing those various types of synergies. Fast integration is often cited as a major determinant of M\&A success (e.g., Gadiesh et al., 2003). However, no empirical evidence on the speed of integration following M\&As exists to date. Next, we rely on the existing literature to identify those deal and bidder characteristics that may bear an effect on the combined firm's stock and accounting performance, and relate them to our own measures. A final contribution of our study is that we analyze M\&A synergies for a sample of recent takeovers in Europe, while research up till now has focused almost exclusively on US/UK transactions, particularly in the 1980s. Considering the larger stake of Europe in the most recent takeover waves, such a focus seems warranted. Moreover, because of the differences in ownership structure and corporate governance, the monitoring of managers by major shareholders is much stronger in Continental Europe, thereby potentially reducing the role of managerial self-serving behavior as an antecedent of acquisitions (see also Huyghebaert and Luypaert, 2010). Besides, and somewhat related to this issue of control, cash deals are far more prevalent in Europe, which also mitigates the role of stock market misvaluation as a driver of external growth decisions. As a result, the nature and magnitude of synergies in European acquisitions could be different from a US sample (e.g., Devos et al., 2009).

In contrast to much of the existing literature, we find that the non-serial acquirers in our sample exhibit a significant positive cumulative abnormal return of $2.68 \%$ on average over the window from 20 days before until one day after deal announcement. We further provide supporting evidence for the idea that operating synergies are substantial. Compared to its non-combining industry peers, the median combined firm in our sample reports a $4.92 \%$ larger sales growth rate by the third post-deal year. Nonetheless, the benchmark-adjusted sales growth rate is significantly negative in the acquisition year, probably reflecting the consolidation of product/brand portfolios. Next, we find evidence of cost-based synergies as of the year of takeover. This outcome indicates that acquiring companies in Europe succeed in integrating their businesses quickly. By the third post-M\&A year, the median decrease in the benchmark-adjusted ratio of operating costs to sales equals a significant $1.53 \%$. These cost-based synergies turn out to arise especially for the category of 'other operating costs'. Finally, we document that acquisitions in Europe have a significant impact on the fraction of assets financed by means of long-term debt. The median combined firm that relies on debt to finance its M\&A exhibits a persistent $6.09 \%$ increase in its long-term debt ratio in the takeover year.

Regarding the determinants of synergy realization, we identify several influential deal and bidder characteristics. First, and most importantly, the acquirer's pre-M\&A market-to-book ratio has a significant positive effect on the magnitude of all types of operating synergies. This result contrasts with what has been found before for glamour bidders (Rau and Vermaelen, 1998), but likely reflects our focus on non-serial acquirers. Next, we show that cost-based synergies are larger in cross-border acquisitions. Yet, large acquirers find it more difficult to realize cost-based synergies, which is in line with prior research (e.g., Moeller et al., 2004; Devos et al., 2009). Finally, highly leveraged bidders and UK bidders achieve larger investment-based synergies, with the effects being somewhat stronger for tangible fixed assets than for net working capital. Regarding financial synergies, we find that (partly) cash-paid acquisitions result in a larger increase in the combined firm's long-term debt ratio. Also, we show that the increase in the long-term debt ratio is larger when the target firm is publicly listed and when the target firm is rather small compared to the bidder. 
The remainder of this paper is organized as follows. In Section 2, we describe our sample and introduce our methodology. We present the results on synergy realization in Section 3, while Section 4 reports on our multivariate regression results. Finally, we offer conclusions in Section 5.

\section{Data}

We used the Zephyr database to identify a sample of completed M\&As in the European Union in the period 1997-2005. (Note 2) In order for a deal to be retained, the bidder as well as the target firm had to have their headquarters in one of the $27 \mathrm{EU}$ countries. We selected all transactions satisfying the following criteria. First, the bidder had to be listed on a European stock exchange and had to acquire full control (i.e. 100\%) of target assets and operations, while holding less than $50 \%$ of shares before the acquisition. So, we started with an initial sample of 3,444 acquisitions. Second, the annual accounts of bidder and target firms had to be included in the Amadeus database, from which the financial statements were collected. (Note 3) As financial firms face different accounting requirements and reporting practices, we also removed the transactions where either the bidder or the target firm has a primary SIC code that starts with 6 . As a result, private-equity deals, where an integration of bidder and target assets and operations does not occur, are not included in the sample either. This criterion reduced the sample to 579 deals. Third, all transactions where the acquirer engaged in another M\&A in a period of three years following the deal under consideration were excluded from the sample. The reason is that we require the post-event window not to be contaminated by any other deal. Consequently, M\&As by bidders that engage in serial acquisitions are removed from the sample, unless the window between subsequent transactions is larger than three years. Applying the latter selection criterion reduced the sample size only by about half, to 293 deals, thereby denoting that non-serial acquirers do account for a non-trivial fraction of the population of acquirers in Europe. (Note 4)

Table 1 provides an overview of the annual (Panel A), industry (Panel B) and country (Panel C) distribution of the sample. Panel A reveals that a majority of takeovers were initiated in 2004 and 2005, while Panel B shows that the industry most represented is personal and business services. $30.72 \%$ of bidders and $37.20 \%$ of targets operate in this industry. Finally, Panel $\mathrm{C}$ shows that almost half of the acquirers are located in the UK.

Table 2 presents a number of deal characteristics for the 293 M\&As in our sample. The sample is dominated by acquisitions, as only $0.68 \%$ of sample deals are mergers. None of the takeovers in the sample is hostile in nature (not reported). $66.21 \%$ of deals are transactions between companies that operate in a different four-digit SIC industry (41.30\% when using two-digit SIC codes). Overall, the acquiring firms come from 141 four-digit SIC industries, while the target firms are active in 129 different industries. Table 2 further reveals that $27.99 \%$ of takeovers are cross-border in nature. Finally, a large majority of M\&As are pure cash transactions $(62.50 \%)$, while only $20.11 \%$ of deals are paid uniquely by means of bidder stock. $17.39 \%$ of deals are thus compensated through a mix of different financial instruments. (Note 5) These numbers are highly comparable to those found in other studies on European M\&As as of the 1990s (e.g., Martynova and Renneboog, 2008; Craninckx and Huyghebaert, 2011). Yet, they are clearly different from those found in US samples. As an example, Wang and Xie (2009) report that $88 \%$ of M\&As in the USA in the period 1990-2004 involved at least some stock compensation.

Table 1. Annual, industry and country distribution of the M\&A sample

Panel A: Annual distribution

\begin{tabular}{lcc}
\hline Year & $N$ & $\%$ \\
\hline 1997 & 3 & $1.02 \%$ \\
1998 & 10 & $3.41 \%$ \\
1999 & 9 & $3.07 \%$ \\
2000 & 4 & $1.37 \%$ \\
2001 & 7 & $2.39 \%$ \\
2002 & 23 & $7.85 \%$ \\
2003 & 47 & $16.04 \%$ \\
2004 & 61 & $20.82 \%$ \\
2005 & 129 & $44.03 \%$ \\
\hline Total & $\mathbf{2 9 3}$ & $\mathbf{1 0 0 . 0 0 \%}$ \\
\hline
\end{tabular}

Description: This panel presents the annual distribution for the sample. 
Panel B: Industry distribution

\begin{tabular}{llcccc}
\hline SIC code & Industry description & \multicolumn{2}{c}{ Bidders } & \multicolumn{2}{c}{ Targets } \\
\hline & & $N$ & $\%$ & 0 & $0.00 \%$ \\
1 & Agriculture & 1 & $0.34 \%$ & 15 & $5.12 \%$ \\
2 & Mining & 13 & $4.44 \%$ & 33 & $11.26 \%$ \\
3 & Food & 43 & $14.68 \%$ & 42 & $14.33 \%$ \\
4 & Manufacturing & 53 & $18.09 \%$ & 28 & $9.56 \%$ \\
5 & Transportation & 25 & $8.53 \%$ & 38 & $12.97 \%$ \\
7 & Wholesale & 40 & $13.65 \%$ & 109 & $37.20 \%$ \\
8 & Personal and business services & 90 & $30.72 \%$ & 28 & $9.56 \%$ \\
\hline Total & Health, legal and social services & 28 & $9.56 \%$ & $\mathbf{2 9 3}$ & $\mathbf{1 0 0 . 0 0 \%}$ \\
\hline
\end{tabular}

Description: This panel presents the industry distribution for the sample.

Panel C: Country distribution

\begin{tabular}{lrrrr}
\hline & \multicolumn{2}{c}{ Acquirers } & \multicolumn{2}{c}{ Targets } \\
\hline & $\mathrm{N}$ & \multicolumn{1}{c}{$\%$} & $\mathrm{~N}$ & \multicolumn{1}{c}{$\%$} \\
\hline Austria & 5 & $1.71 \%$ & 2 & $0.68 \%$ \\
Belgium & 7 & $2.39 \%$ & 5 & $1.71 \%$ \\
Czech Republic & 0 & $0.00 \%$ & 3 & $1.02 \%$ \\
Denmark & 3 & $1.02 \%$ & 7 & $2.39 \%$ \\
Estonia & 2 & $0.68 \%$ & 1 & $0.34 \%$ \\
Finland & 13 & $4.44 \%$ & 7 & $2.39 \%$ \\
France & 40 & $13.65 \%$ & 48 & $16.38 \%$ \\
Germany & 16 & $5.46 \%$ & 9 & $3.07 \%$ \\
Greece & 8 & $2.73 \%$ & 8 & $2.73 \%$ \\
Hungary & 0 & $0.00 \%$ & 1 & $0.34 \%$ \\
Italy & 17 & $5.80 \%$ & 20 & $6.83 \%$ \\
Latvia & 0 & $0.00 \%$ & 4 & $1.37 \%$ \\
Lithuania & 1 & $0.34 \%$ & 1 & $0.34 \%$ \\
Netherlands & 11 & $3.75 \%$ & 12 & $4.10 \%$ \\
Poland & 9 & $3.07 \%$ & 14 & $4.78 \%$ \\
Portugal & 0 & $0.00 \%$ & 2 & $0.68 \%$ \\
Slovakia & 0 & $0.00 \%$ & 1 & $0.34 \%$ \\
Slovenia & 2 & $0.68 \%$ & 2 & $0.68 \%$ \\
Spain & 12 & $4.10 \%$ & 11 & $3.75 \%$ \\
Sweden & 14 & $4.78 \%$ & 17 & $5.80 \%$ \\
United Kingdom & 133 & $45.39 \%$ & 118 & $40.27 \%$ \\
\hline Total & $\mathbf{2 9 3}$ & $\mathbf{1 0 0 . 0 0 \%}$ & $\mathbf{2 9 3}$ & $\mathbf{1 0 0 . 0 0 \%}$ \\
\hline
\end{tabular}

Description: This panel presents the country distribution for the sample.

Table 2. Deal characteristics

\begin{tabular}{|c|c|c|c|c|c|c|c|c|c|c|c|}
\hline & 1997 & 1998 & 1999 & 2000 & 2001 & 2002 & 2003 & 2004 & 2005 & Total & $\%$ \\
\hline Merger & 0 & 0 & 0 & 0 & 0 & 0 & 2 & 0 & 0 & 2 & $0.68 \%$ \\
\hline Acquisition & 3 & 12 & 9 & 4 & 4 & 22 & 45 & 64 & 128 & 291 & $99.32 \%$ \\
\hline Industry-related & 0 & 3 & 3 & 2 & 0 & 6 & 12 & 28 & 45 & 99 & $33.79 \%$ \\
\hline Industry-diversifying & 3 & 9 & 6 & 2 & 4 & 16 & 35 & 36 & 83 & 194 & $66.21 \%$ \\
\hline Domestic & 3 & 8 & 7 & 2 & 3 & 16 & 33 & 47 & 92 & 211 & $72.01 \%$ \\
\hline Cross-border & 0 & 4 & 2 & 2 & 1 & 6 & 14 & 17 & 36 & 82 & $27.99 \%$ \\
\hline All-cash bid & 2 & 2 & 2 & 2 & 1 & 7 & 16 & 25 & 58 & 115 & $62.50 \%$ \\
\hline All-equity bid & 0 & 1 & 1 & 0 & 2 & 5 & 5 & 11 & 12 & 37 & $20.11 \%$ \\
\hline Mixed-payment bid & 0 & 2 & 2 & 0 & 0 & 1 & 4 & 7 & 16 & 32 & $17.39 \%$ \\
\hline
\end{tabular}

Description: This table reports the deal characteristics of the sample, year by year. Specifically, the table reports the number of M\&As, the number of industry-related versus industry-diversifying transactions (according to primary four-digit SIC codes), the number of domestic versus cross-border deals, the number of deals that were paid entirely in cash, in stock, or through a combination of different financial instruments. 
Table 3 presents descriptive statistics on various firm characteristics in the year before the acquisition. The data are winsorized at 5\%-95\% to deal with outliers. We report separate statistics for bidders and for targets, together with the $p$-values of a parametric $t$-test as well as a non-parametric Wilcoxon rank-sum test. While all acquirers are listed by sample construction, only $3.75 \%$ of target firms are publicly quoted. Table 3 allows concluding that bidders on average have a smaller total debt ratio (average of $42.10 \%$ ), but a larger long-term debt ratio (average of $16.26 \%$ ). According to the Wilcoxon rank-sum test, bidders also hold significantly larger cash reserves. Moreover, in line with previous research, acquiring companies exhibit superior performance in the pre-M\&A year. The average bidder has an ROA of $5.00 \%$ and an ROS of $3.47 \%$. Next, bidders are larger than their takeover targets, in terms of sales as well as total assets. They do not differ in terms of market capitalization, yet the latter variable could only be calculated for a limited fraction of target firms. Finally, the bidder market-to-book ratio of equity averages to 2.40, which is not significantly different from the 2.36 average for listed target firms.

Table 3. Firm characteristics

\begin{tabular}{lrrrrrrrr}
\hline & \multicolumn{3}{c}{ Bidders } & \multicolumn{3}{c}{ Targets } & \multicolumn{3}{c}{ p-value for difference } \\
\hline & Mean & Median & Std. Dev & Mean & Median & Std. Dev $\begin{array}{c}\text { Parametri } \\
\text { c Wilcoxon } \\
\text { rank-sum } \\
\text { test }\end{array}$ \\
\hline Leverage (total debt) & $42.10 \%$ & $42.44 \%$ & $18.40 \%$ & $50.05 \%$ & $46.87 \%$ & $29.32 \%$ & $\mathbf{0 . 0 0 0 1}$ & $\mathbf{0 . 0 0 6 0}$ \\
Leverage (long-term & & & & & & & & \\
debt) & $16.26 \%$ & $11.03 \%$ & $15.17 \%$ & $13.55 \%$ & $4.92 \%$ & $19.31 \%$ & $\mathbf{0 . 0 5 9 1}$ & $\mathbf{0 . 0 0 0 0}$ \\
Cash ratio & $12.61 \%$ & $8.14 \%$ & $12.82 \%$ & $13.02 \%$ & $6.53 \%$ & $15.90 \%$ & 0.7285 & $\mathbf{0 . 0 3 2 7}$ \\
ROA & $5.00 \%$ & $7.34 \%$ & $12.63 \%$ & $1.90 \%$ & $5.93 \%$ & $26.88 \%$ & $\mathbf{0 . 0 7 4 2}$ & 0.5642 \\
ROS & $3.47 \%$ & $6.30 \%$ & $17.39 \%$ & $-1.80 \%$ & $3.18 \%$ & $26.69 \%$ & $\mathbf{0 . 0 0 4 8}$ & $\mathbf{0 . 0 0 0 4}$ \\
Sales (th EUR) & 853,881 & 166,678 & $1,608,910$ & 34,425 & 9,317 & 55,601 & $\mathbf{0 . 0 0 0 0}$ & $\mathbf{0 . 0 0 0 0}$ \\
Total assets (th EUR) & 968,338 & 149,762 & $2,066,395$ & 24,178 & 6,527 & 42,031 & $\mathbf{0 . 0 0 0 0}$ & $\mathbf{0 . 0 0 0 0}$ \\
Market cap (th EUR) & 944,810 & 167,864 & $1,864,037$ & $1,324,421$ & 30,450 & $2,285,578$ & 0.5976 & 0.2277 \\
Market-to-book of equity & 2.40 & 1.72 & 2.00 & 2.36 & 1.88 & 1.79 & 0.9535 & 0.8417 \\
\hline
\end{tabular}

Description: This table reports summary statistics on bidder and target characteristics in the pre-M\&A year.

\section{Methodology}

We first introduce the event study methodology to impound the assessment of an acquisition by stock market investors upon its first public notification. This methodology may provide us with an estimate of synergies expected by stock market investors at the time of deal announcement. Next, we discuss how the various sources of synergies can be determined from the financial statements of the combining companies. Operating synergies refer to the benefits from integrating the operations of the bidder and the target firm. We distinguish between revenue-based, cost-based, and investment-based operating synergies by analyzing the evolution of sales, operating expenses, and investments in net working capital as well as in tangible fixed assets in a three-year window following deal completion. Besides, we identify financial synergies from inspecting the change in the newly combined firm's debt ratio as of deal completion.

\subsection{Bidder Announcement Returns}

Event studies rely on the assumption that financial markets are semi-strong efficient, i.e. share prices reflect all publicly available information. Hence, stock market investors will impound the economic gains arising from synergies and/or a change in control in the stock price of the combining firms at deal announcement. We therefore define the bidder abnormal return as the difference between the bidder's actually realized return and its expected return. Expected returns are calculated using the market model, which is estimated during a clean period [-250,-51] relative to the event date (day 0), in order to prevent parameter estimates from being influenced by the event (Brown and Warner, 1985). (Note 6) We use the S\&P Europe 350 index to proxy for the market and test the significance of the abnormal returns using the standard significance test developed by Dodd and Warner (1983). (Note 7) Besides, we implement the non-parametric test developed by Corrado (1989).

We apply the same methodology to calculate the target CAR and also, following Houston et al. (2001), the combined bidder and target abnormal return around M\&A announcement. Yet, as only a small fraction of target firms are publicly quoted, the latter results are to be interpreted with caution. 


\subsection{Revenue-Enhancement Synergies}

Revenue-enhancement synergies refer to the increase in sales from integrating the operations of bidder and target firms. This type of synergies may arise from sharing complementary resources. For example, the combined firm may be able to expand its sales by using its access to a larger distribution network, thereby increasing its organizational and marketing effectiveness. Alternatively, the combined firm may be able to generate extra sales when the bidder's brand name is used to market the target's products, or vice versa. Finally, Capron (1999) argues that an improved post-deal innovation capability could produce extra sales, for example from adding new product features.

If a takeover engenders revenue-enhancement synergies, then the combined sales growth rate should exceed the change that would have happened to the combining companies if they had stayed independent. To identify abnormal changes in the level of sales of the combined firm, we compare the bidder as well as the takeover target with a benchmark firm in its own industry (see also Gugler et al., 2003). We require all potential matching firms to have not been involved in an M\&A from two years before until three years after the deal under consideration. We rank all potential matching firms in the same four-digit SIC industry and having a similar firm size (i.e. sales) as the sample firms by their ratio of EBITDA to sales. (Note 8) Finally, we select each of the matching firms as the firm with an EBITDA/sales ratio closest to that of the bidder and target firm, respectively. Barber and Lyon (1996) demonstrate that test statistics are well-specified when matching firms are also chosen based upon pre-event performance. (Note 9) Likewise Gugler et al. (2003), we now can calculate the expected value of sales realized by the combined firm in year $\mathrm{t}+\mathrm{n}$ after deal completion if the takeover had not engendered any revenue-enhancement synergies. So, $S_{C_{t+n} n}$ is computed as follows:

$$
S_{C t+n}=S_{B t-1} \frac{S_{I B t+n}}{S_{I B t-1}}+S_{T t-1} \frac{S_{I T t+n}}{S_{I T t-1}}
$$

where:

$$
\begin{array}{ll}
S_{B t-l}: & \text { sales of the bidding company in year } t-1 \\
S_{I B t-1}, S_{I B t+n}: & \text { sales of the matching firm in the bidder industry in year } t-1(t+n) \\
S_{T t-l}: & \text { sales of the target company in year } t-1 \\
S_{I T t-1}, S_{I T t+n}: & \text { sales of the matching firm in the target industry in year } t-1(t+n)
\end{array}
$$

Finally, we compare the actual value of sales of the combined firm with its benchmark value in equation (1). Thereafter, we divide this difference by the sum of bidder and target sales in the year before the takeover.

\subsection{Cost-based Synergies}

Cost-based synergies may arise from economies of scale and/or economies of scope. Economies of scale can be achieved when the fixed costs of operations can be spread over a larger number of units. This type of cost reductions can be realized in the different functional areas of a business, like, for example, R\&D, procurement, production, distribution, or administration. Besides, an increase in output volume may also entail a larger specialization of labor and management. Economies of scope, on the other hand, can be achieved when the costs of producing and distributing multiple products by one company are lower than when having them produced by separate firms. The latter cost savings may show up when bidder and target firms can share a unique factor of production, like technology or distribution channels. If those types of cost savings can be accomplished by means of M\&As, the combined firm's ratio of operating expenses to sales will decline as of the acquisition. In order to investigate the effects of an M\&A on operating costs, we compute the change in the benchmark-adjusted ratio of operating costs to sales as follows:

$$
\text { Abnormal change in operating costs/sales }{ }_{t+n}=\mathrm{OC} / \mathrm{S}_{\text {adjusted, } \mathrm{t}+\mathrm{n}}-\mathrm{OC} / \mathrm{S}_{\text {adjusted, } \mathrm{t}-1}
$$

with: $\quad \mathrm{OC} / \mathrm{S}_{\text {adjusted, } t+n}=\mathrm{OC} / \mathrm{S}_{\text {combined firm, } t+n}-\mathrm{OC} / \mathrm{S}_{\text {benchmark, } t+n}$

$\mathrm{OC} / \mathrm{S}_{\text {adjusted, } \mathrm{t}-1}=\mathrm{OC} / \mathrm{S}_{\text {bidder }+ \text { target, } \mathrm{t}-1}-\mathrm{OC} / \mathrm{S}_{\text {benchmark, } t-1}$

$\mathrm{OC} / \mathrm{S}_{\text {benchmark, } t+n(t-1)}=$ Weighted average of the matching firms' ratio of operating costs to sales in years $\mathrm{t}+\mathrm{n}$ $(\mathrm{t}-1)$, using bidder and target pre-M\&A size (i.e. sales) as weighting factors:

$$
O C / S_{\text {benchmark }, t+n}=\frac{S_{B t-1}}{S_{B t-1}+S_{T t-1}} \times \frac{O C_{I B t+n}}{S_{I B t+n}}+\frac{S_{T t-1}}{S_{B t-1}+S_{T t-1}} \times \frac{O C_{I T t+n}}{S_{I T t+n}}
$$

Likewise our earlier calculation of revenue-enhancement synergies, the above methodology for calculating cost-based synergies allows accounting for changes in production technology and innovations that affect all companies in the same industry. 
When paying for goodwill in an acquisition, the acquirer has to depreciate this goodwill every year (before the introduction of IFRS accounting rules) or has to report impairment losses on goodwill when this goodwill is no longer justified (under IFRS rules). As a result, the reported changes in operating costs could be influenced by these goodwill-related (non-cash) expenses. We therefore exclude goodwill depreciation and impairment losses on goodwill when investigating the evolution of operating costs over time. As information on the depreciation or impairment of goodwill is not included in the Amadeus database, we had to collect these data from Datastream.

Besides, we consider the post-M\&A evolution of different subcategories of operating expenses, i.e. 'costs of goods sold', 'costs of employees', and 'other operating costs'. Costs of goods sold are all expenses directly related to the production of goods, including depreciation. Costs of employees include the wages paid to personnel, social security expenses, and pension costs. Finally, other operating costs cover the expenses that are not directly related to production, consisting mostly of selling, general, and administrative expenses. The latter cost category thus represents the costs related to the sale of products and to the management function; it includes advertising costs, rent, insurance, utilities, and managerial salaries. Unfortunately, the decomposition of operating costs is not included in Amadeus for all event and matching firms in the sample. In the year of acquisition, for example, data on 'costs of goods sold' and 'other operating costs' are available for only 116 out of 293 observations (i.e. data available for bidders, targets, as well as their matching firms), whereas the information on 'costs of employees' is available for only 236 deals.

\subsection{Investment-based Synergies}

Operating synergies can also stem from cutbacks in investments, resulting in a more efficient use of capital equipment (e.g., Gaughan, 2002; Devos et al., 2009). When two firms combine, they can indeed improve the efficiency of their investments by sharing particular assets, like an office building, a factory, or machinery. Also, efficiencies in net working capital can be achieved by improving cash collection (i.e. lower accounts receivable) or by reducing inventories. Moreover, a larger post-deal bargaining power vis-à-vis input suppliers may lead to extra trade finance (i.e. larger accounts payable). We examine the role of those asset reductions as a source of operating synergies by investigating the benchmark-adjusted change in the ratios of net working capital (= non-cash current assets minus non-financial short-term liabilities) relative to sales and tangible fixed assets relative to sales. These proxies for investment-based synergies are calculated in a manner that is identical to our measures of cost-based synergies.

\subsection{Financial Synergies}

Finally, financial synergies may arise from an increase in the debt ratio of the combined firm. When two firms with less than perfectly correlated cash flows combine, their default risk tends to decline, due to a coinsurance effect. Accordingly, their borrowing capacity grows larger and so, by relying more on debt to finance their assets and operations, they could realize a bigger debt tax shield from interest expenses. Besides, combined firms may be able to reduce their cost of debt, particularly when the income of the combined entity is less risky than that of the stand-alone firms. Together with the increased debt tax shield, this allows to further reduce the cost of capital.

In this article, we investigate the existence of financial synergies by studying the change in leverage from before to after the acquisition Likewise, we focus on the change in the ratio of long-term debt, typically bank loans and corporate bonds. To that end, we compare the post-M\&A (long-term) debt ratio of the combined firm with the pre-M\&A weighted average of bidder and target firms.

\section{Empirical Results}

\subsection{Synergy Realization after the Acquisition}

Table 4 reports summary statistics on the bidder cumulative abnormal return over different event windows. Our analyses start 50 trading days before the actual deal announcement date, to account for the typical stock price run-up preceding the first public notification of the deal. This run-up may arise from information leakage and/or insider trading, thereby anticipating part of the M\&A value creation (e.g., Craninckx and Huyghebaert, 2011). Although prior studies in general report a negative or, at best, an insignificant bidder announcement return (e.g., Andrade et al., 2001; Martynova and Renneboog, 2008; Bouwman et al., 2009), we find that the shareholders of the acquiring firm gain significantly upon deal announcement. Over the three-day window surrounding the M\&A announcement date, the average bidder CAR equals a highly significant $1.21 \%$. This number increases to $2.68 \%$ once the event window is extended to 20 days before actual deal announcement, to account for the typical stock price run-up (see Figure 1). However, the largest stock price reaction takes place on the event date itself. Our findings regarding the bidder CAR are also more positive than what has been documented before in studies examining European acquisitions (see, for 
example, Martynova and Renneboog, 2008; Craninckx and Huyghebaert, 2011). Arguably, our more positive conclusions on the bidder CAR is reflecting our focus on non-serial acquirers. A number of recent articles has also provided evidence of a lower bidder CAR for serial acquirers (e.g., Ismail, 2008; Aktas et al., 2011). Moreover, Panel B of Table 4 shows that the bidder CAR does not differ consistently, depending upon whether the target firm is publicly listed or not. If anything, we find some weak evidence that the bidder CAR is larger when the target firm is stock-market quoted. This finding contrasts with previous research, documenting a larger bidder CAR for privately-held target firms (e.g., Draper and Paudyal, 2006). Overall, the results in Panel B of Table 4 allow us to clearly rule out an alternative explanation for our finding of a significant positive bidder CAR, namely that it is merely reflecting the large fraction of private target firms in our sample.

For the subsample of M\&As targeting publicly listed firms, we find that the average target CAR over the event window $[-20,+1]$ equals a significant $11.21 \%$ (not reported in Table 4 ). The combined bidder and target CAR then averages to a significant $5.29 \%$ for these acquisitions. Interestingly, and in line with Wang and Xie (2009), we find that the bidder CAR and the combined CAR are positively correlated for those deals $(\rho=0.5510)$.

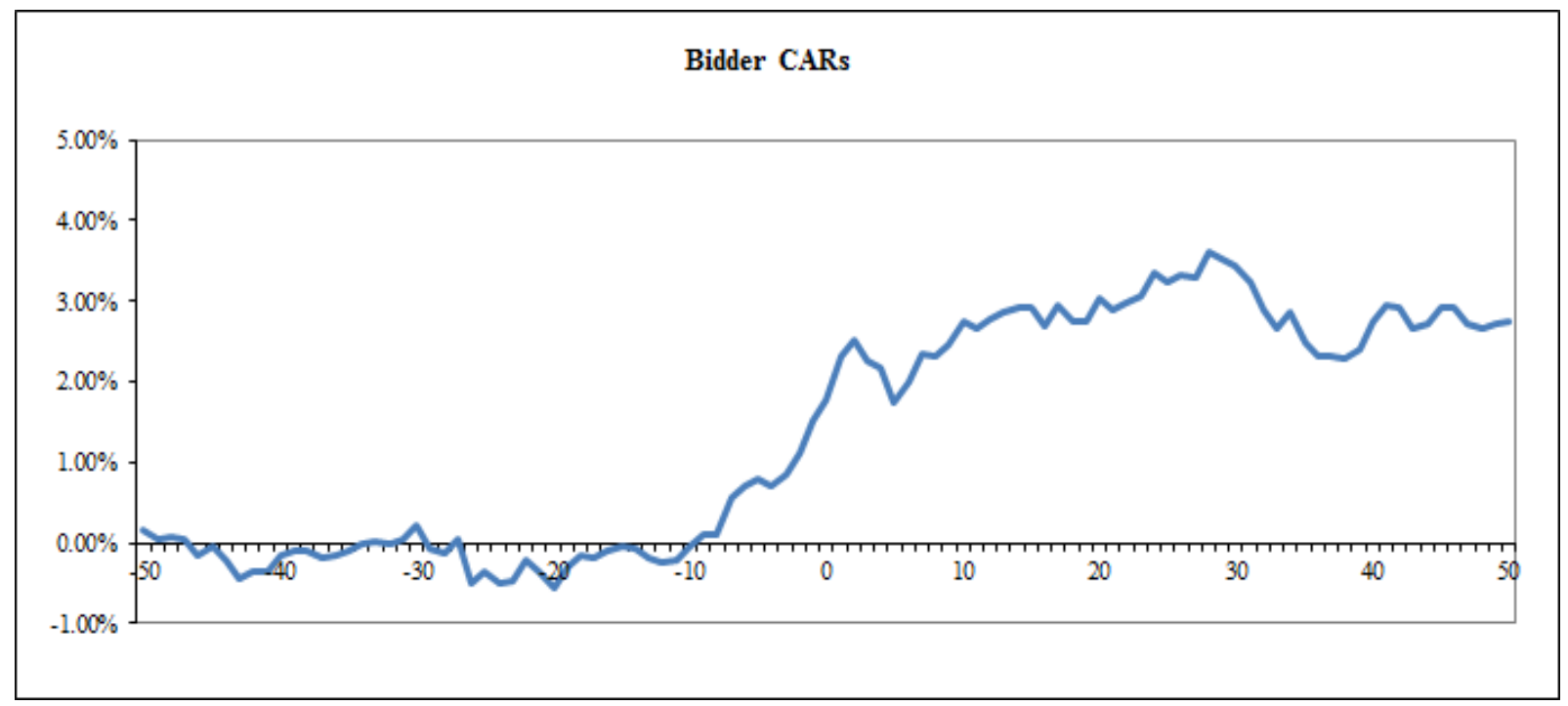

Figure 1. Bidder cumulative abnormal returns over the event window from 50 days before until 50 days after M\&A announcement (day 0)

Table 4. Bidder cumulative abnormal return

Bidder CAR

\section{Panel A: aggregate sample}

Event window

Average CAR (\%)

Median CAR (\%)

Corrado t-statistic t-statistic

$$
[-1,0]
$$

$$
0.65 \%
$$

$0.53 \%$

2.85

4.71

Panel B: subsample analysis

Average CAR (\%) if target is private

Average CAR (\%) if target is listed

$p$-value for difference

$\begin{array}{rr}0.73 \% & 1.00 \% \\ -1.52 \% & 6.51 \% \\ 0.3525 & \mathbf{0 . 0 6 0 3}\end{array}$

$[-1,+1]$

$1.21 \%$

$0.64 \%$

4.31

4.77
$[-5,+1]$

$1.61 \%$

$0.68 \%$

3.89

3.44
$[-20,+1]$

$2.68 \%$

$0.77 \%$

3.69

2.73
$[-35,+1]$

$2.48 \%$

$1.13 \%$

3.06

1.46
$[-50,+1]$

$2.33 \%$

$1.48 \%$

2.43

1.66

Description: This table reports summary statistics on the bidder cumulative abnormal return (CAR) surrounding M\&A announcement. Expected returns are calculated using the market model, which is estimated during a clean window $[-250,-51]$ relative to the event date (day 0). The S\&P Europe 350 index is used to proxy for the market. 
Next, we examine what types of synergies are actually realized. Table 5 displays summary statistics as to the realization of revenue-enhancement synergies over different event windows, based upon equation (1). (Note 10) First, in the acquisition year, the average abnormal sales growth rate of $-5.10 \%$ (median of $-4.40 \%$ ) indicates that the combined firm's sales growth is significantly below that of its non-combining industry peers. This finding could reflect the consolidation of product/brand portfolios. Next, the benchmark-adjusted sales growth rates in subsequent years are all significantly positive. The largest jump in sales growth takes place in the first year following the acquisition. Combined sales keep rising faster than the benchmark in the second post-M\&A year, with abnormal sales growth stabilizing more or less as of this year. Compared with its non-combining industry peers, the average (median) combined firm shows a sales growth rate that is $9.71 \%(4.92 \%)$ above the benchmark by the third post-deal year. In order to deal with the benchmark issues raised by Harford (2005), we have also calculated post-M\&A sales growth rates without benchmark adjustment. The results point out that sales grow by an insignificant $0.86 \%$ in the M\&A year and by a highly significant $36.93 \%$ by the third post-M\&A year (not reported). Next, to deal with a potential survivorship bias, we have computed benchmark-adjusted sales growth rates for the firms that could be traced over the full three-year post-M\&A window. The abnormal sales growth rates turned out to be highly comparable to those reported in Table 5.

Table 5. Revenue-enhancement synergies

\begin{tabular}{|c|c|c|c|c|}
\hline & & & & $p$-value \\
\hline Year & $\begin{array}{l}\text { Number of } \\
\text { observations }\end{array}$ & Mean & Median & $\begin{array}{cc}\text { Parametric } & \text { Wilcoxon } \\
\text { t-test } & \text { rank-sum test }\end{array}$ \\
\hline
\end{tabular}

$\begin{array}{ccccccc} & \mathrm{t} & 293 & -5.10 \% & -4.40 \% & \mathbf{0 . 0 0 0 0} & \mathbf{0 . 0 0 0 0} \\ \text { Abnormal changes in sales } & \mathrm{t}+1 & 285 & 6.25 \% & 2.16 \% & \mathbf{0 . 0 0 0 1} & \mathbf{0 . 0 0 0 8} \\ & \mathrm{t}+2 & 276 & 8.31 \% & 3.59 \% & \mathbf{0 . 0 0 0 2} & \mathbf{0 . 0 0 0 7} \\ & \mathrm{t}+3 & 253 & 9.71 \% & 4.92 \% & \mathbf{0 . 0 0 1 3} & \mathbf{0 . 0 0 2 3}\end{array}$

Description: This table reports summary statistics on the difference between the actual values of sales and the corresponding predicted values scaled by the combined bidder and target value of sales in the year before the deal.

Table 6 shows summary statistics on the benchmark-adjusted ratios of operating costs to sales for different event windows. Panel A presents our findings for total operating costs, while Panel B reports more detailed information for the various subcategories of operating costs. The results in Panel A reveal considerable cost savings as of the acquisition year. The average (median) combined firm is able to reduce its operating expenses by a significant $1.56 \%$ $(1.02 \%)$ already in the year of takeover. This finding indicates that acquirers succeed in integrating the target's operations quickly and, hence, realize cost-based synergies quite fast. Also, these cost synergies are achieved in every year after the M\&A. Acquisitions thus have an enduring effect on the cost structure of the combining companies. The average (median) decline in the benchmark-adjusted ratio of operating expenses to sales equals a significant $1.35 \%(1.53 \%)$ by the third post-M\&A year. When calculating post-M\&A ratios of operating costs to sales without benchmark adjustment, we find that the average abnormal change equals $-1.44 \%$ in the year of the acquisition and amounts to $-2.07 \%$ by the third post-M\&A year (not reported). Our findings also remain valid once considering the subsample of combined firms that could be traced over the full three-year window after deal completion (not reported).

Next, the results in Panel B of Table 6 point out that the decline in post-M\&A operating costs does not arise for all types of operating expenses. In fact, cost-based synergies seem to arise only for the subcategory of 'other operating costs'. These savings may stem from, for example, spreading the fixed costs of selling (e.g., advertising expenditures) or administration (e.g., office supplies) over a larger production volume. For the other cost categories (i.e. 'costs of goods sold' and 'costs of employees'), we even note a small, but significant increase in the first few years after deal completion. The abnormal rise in the costs of employees as of the acquisition is remarkable, yet in line with the findings by McGuckin and Nguyen (2001). The latter scholars provide evidence of an increase in plant-level employment and wages following ownership restructurings. Possibly, by hiring more and/or better trained personnel at the target level, the bidder can realize an improvement of target performance. Table 3 indeed revealed that, in comparison with the bidders, the target firms in our sample exhibit inferior performance before their takeover. 
Table 6. Cost-based synergies

Panel A: Total operating costs

\begin{tabular}{|c|c|c|c|c|c|c|}
\hline & \multirow[b]{2}{*}{ Year } & \multirow[b]{2}{*}{$\begin{array}{l}\text { Number of } \\
\text { observations }\end{array}$} & \multirow[b]{2}{*}{ Mean } & \multirow[b]{2}{*}{ Median } & \multicolumn{2}{|c|}{ p-value } \\
\hline & & & & & $\begin{array}{c}\text { Parametric } \\
\text { t-test }\end{array}$ & $\begin{array}{c}\text { Wilcoxon } \\
\text { rank-sum test }\end{array}$ \\
\hline \multirow{4}{*}{ Abnormal change in operating costs/sales } & $\mathrm{t}$ & 293 & $-1.56 \%$ & $-1.02 \%$ & 0.0000 & 0.0001 \\
\hline & $t+1$ & 285 & $-1.77 \%$ & $-1.06 \%$ & 0.0000 & 0.0000 \\
\hline & $t+2$ & 276 & $-1.84 \%$ & $-0.88 \%$ & 0.0000 & 0.0000 \\
\hline & $t+3$ & 253 & $-1.35 \%$ & $-1.53 \%$ & 0.0000 & 0.0000 \\
\hline \multicolumn{7}{|l|}{ Panel B: Split-up of operating costs } \\
\hline & \multirow[b]{2}{*}{ Year } & \multirow{2}{*}{$\begin{array}{l}\text { Number of } \\
\text { observations }\end{array}$} & \multirow[b]{2}{*}{ Mean } & \multirow[b]{2}{*}{ Median } & \multicolumn{2}{|c|}{ p-value } \\
\hline & & & & & $\begin{array}{c}\text { Parametric } \\
\text { t-test }\end{array}$ & $\begin{array}{c}\text { Wilcoxon } \\
\text { rank-sum test }\end{array}$ \\
\hline \multirow{4}{*}{ Abnormal change in costs of goods sold/sales } & $\mathrm{t}$ & 116 & $2.98 \%$ & $0.22 \%$ & 0.0007 & 0.0674 \\
\hline & $\mathrm{t}+1$ & 113 & $3.24 \%$ & $0.45 \%$ & 0.0006 & 0.0358 \\
\hline & $\mathrm{t}+2$ & 107 & $6.39 \%$ & $2.31 \%$ & 0.0000 & 0.0005 \\
\hline & $\mathrm{t}+3$ & 90 & $1.70 \%$ & $0.86 \%$ & 0.0774 & 0.0949 \\
\hline \multirow{4}{*}{ Abnormal change in costs of employees/sales } & $\mathrm{t}$ & 236 & $0.50 \%$ & $0.43 \%$ & 0.0039 & 0.0027 \\
\hline & $\mathrm{t}+1$ & 232 & $0.51 \%$ & $0.40 \%$ & 0.0493 & 0.0275 \\
\hline & $\mathrm{t}+2$ & 220 & $0.09 \%$ & $0.18 \%$ & 0.7323 & 0.1740 \\
\hline & $\mathrm{t}+3$ & 192 & $0.52 \%$ & $0.04 \%$ & 0.1463 & 0.0420 \\
\hline \multirow{4}{*}{ Abnormal change in other operating costs/sales } & $\mathrm{t}$ & 116 & $-3.56 \%$ & $-1.99 \%$ & 0.0006 & 0.0021 \\
\hline & $\mathrm{t}+1$ & 112 & $-6.01 \%$ & $-3.11 \%$ & 0.0000 & 0.0000 \\
\hline & $t+2$ & 108 & $-4.05 \%$ & $-0.99 \%$ & 0.0001 & 00133 \\
\hline & $t+3$ & 92 & $-0.71 \%$ & $-0.71 \%$ & 0.4844 & 0.2011 \\
\hline
\end{tabular}

Description: This table reports summary statistics on the change in the benchmark-adjusted ratio of operating costs to sales. Panel A reports the results for total operating costs, whereas Panel B displays the abnormal changes for the different subcategories of operating costs.

Table 7 shows summary statistics on the benchmark-adjusted ratios of net working capital to sales for the different event windows. We find no significant changes in the average and median investment in net working capital in the first two years after the acquisition. However, the average (median) benchmark-adjusted ratio of net working capital to sales increases by a significant $4.43 \%(2.81 \%)$ by the third post-deal year. Likewise, the results in Table 8 point out that the combined firms in our sample do not engage in asset divestitures. The benchmark-adjusted change in the ratio of tangible fixed assets to sales is even significantly positive in the year of takeover and in the second and third post-M\&A year. Our findings regarding investment-based synergies are confirmed when examining the raw data without benchmark adjustment. Unreported analyses also show that the abnormal change in tangible fixed assets is significantly larger for the subsample of deals initiated by Continental European bidders than for deals initiated by UK bidders (average of $1.92 \%$ versus $-0.23 \%$ by the third post-M\&A year).

Together, the results in Tables 7 and 8 clearly indicate that the operating synergies realized by non-serial acquirers in Europe in general do not arise from cutbacks in investment expenditures. This conclusion undoubtedly contrasts with the findings by Devos et al. (2009), which likely reflects a difference in motives underlying M\&As. Devos et al. investigate deals from the fourth M\&A wave, while we only consider transactions as of the fifth wave. The fourth M\&A wave, taking place particularly in the USA/UK, has been characterized by a disciplining of target management through the market for corporate control and by a heavy reliance on debt to finance these (hostile) takeovers. As a result, many target assets were divested after deal completion, to reinstall the focus on firm value and to pay off the raised debts. In contrast, the M\&As as of the fifth wave were largely driven by strategic considerations. For those deals, global competition, technological innovation, and the liberalization and integration of markets, particularly in Europe, were an important impetus (e.g., Martynova and Renneboog, 2008; Huyghebaert and Luypaert, 2010). Probably, those forces were especially relevant for the firms that did not let themselves urge into acquisitions because of transient windows of opportunity engendered by soaring stock prices. So, when those firms pursued 
M\&As to deal with the changes in fundamental parameters, thereby implementing adjustments to the structure of their businesses, they may have proved able to realize substantial revenue-enhancement synergies and/or cost-based synergies.

Table 7. Cutbacks in net working capital

\begin{tabular}{|c|c|c|c|c|c|c|}
\hline & \multirow[b]{2}{*}{ Year } & \multirow[b]{2}{*}{$\begin{array}{c}\text { Number of } \\
\text { observations }\end{array}$} & \multirow[b]{2}{*}{ Mean } & \multirow[b]{2}{*}{ Median } & \multicolumn{2}{|c|}{ p-value } \\
\hline & & & & & $\begin{array}{c}\text { Parametric } \\
\text { t-test }\end{array}$ & $\begin{array}{c}\text { Wilcoxon } \\
\text { rank-sum test }\end{array}$ \\
\hline \multirow{4}{*}{ Abnormal change in net working capital/sales } & $\mathrm{t}$ & 271 & $0.30 \%$ & $-0.29 \%$ & 0.3358 & 0.1311 \\
\hline & $\mathrm{t}+1$ & 267 & $-0.08 \%$ & $-1.04 \%$ & 0.8914 & 0.4648 \\
\hline & $\mathrm{t}+2$ & 252 & $1.47 \%$ & $0.56 \%$ & 0.0297 & 0.0232 \\
\hline & $\mathrm{t}+3$ & 225 & $4.43 \%$ & $2.81 \%$ & 0.0000 & 0.0000 \\
\hline
\end{tabular}

Description: This table reports summary statistics on the change in the benchmark-adjusted ratio of net working capital to sales.

Table 8. Cutbacks in investments in tangible fixed assets

\begin{tabular}{|c|c|c|c|c|c|c|}
\hline & \multirow[b]{2}{*}{ Year } & \multirow[b]{2}{*}{$\begin{array}{l}\text { Number of } \\
\text { observations }\end{array}$} & \multirow[b]{2}{*}{ Mean } & \multirow[b]{2}{*}{ Median } & \multicolumn{2}{|c|}{$p$-value } \\
\hline & & & & & $\begin{array}{c}\text { Parametric } \\
\text { t-test }\end{array}$ & $\begin{array}{c}\text { Wilcoxon } \\
\text { rank-sum test }\end{array}$ \\
\hline \multirow{4}{*}{ Abnormal change in tangible fixed assets/sales } & $\mathrm{t}$ & 274 & $1.27 \%$ & $0.62 \%$ & 0.0000 & 0.0000 \\
\hline & $\mathrm{t}+1$ & 269 & $0.09 \%$ & $-0.27 \%$ & 0.7692 & 0.2404 \\
\hline & $\mathrm{t}+2$ & 255 & $1.84 \%$ & $0.14 \%$ & 0.0000 & 0.0027 \\
\hline & $t+3$ & 228 & $0.95 \%$ & $-0.04 \%$ & 0.0645 & 0.1103 \\
\hline
\end{tabular}

Description: This table reports summary statistics on the change in the benchmark-adjusted ratio of tangible fixed assets to sales.

Table 9 reports our findings as to the realization of financial synergies. We conclude that the newly combined firms in our sample rely more on debt, particularly long-term debt, to finance their activities in the post-M\&A window. The corresponding increase in the (long-term) debt ratio is significant as of the takeover year, resulting in an average increase by $2.01 \%(2.28 \%)$. When focusing on the subsample of firms that enhanced their (long-term) debt ratio in the takeover year (more than half of sample firms), we find an average increase in (long-term) leverage by $8.16 \%$ (6.97\%). This upsurge in debt seems to persist over time, as the average change in the (long-term) debt ratio still equals $8.18 \%(6.02 \%)$ by the third post-deal year. (Note 11$)$ The median numbers are highly comparable. Overall, our findings on financial synergies are in line with those of Ghosh and Jain (2000), who study a sample of 239 US mergers during 1978-1987.

Table 9. Measures of financial synergies

\begin{tabular}{|c|c|c|c|c|c|c|}
\hline & \multirow[b]{2}{*}{ Year } & \multirow[b]{2}{*}{$\begin{array}{l}\text { Number of } \\
\text { observations }\end{array}$} & \multirow[b]{2}{*}{ Mean } & \multirow[b]{2}{*}{ Median } & \multicolumn{2}{|c|}{$p$-value } \\
\hline & & & & & $\begin{array}{c}\text { Parametric } \\
\text { t-test }\end{array}$ & $\begin{array}{c}\text { Wilcoxon } \\
\text { rank-sum } \\
\text { test }\end{array}$ \\
\hline \multirow{4}{*}{ Change in total debt ratio } & $\mathrm{t}$ & 290 & $2.01 \%$ & $0.46 \%$ & 0.0000 & 0.0068 \\
\hline & $\mathrm{t}+1$ & 288 & $1.74 \%$ & $1.29 \%$ & 0.0127 & 0.0284 \\
\hline & $\mathrm{t}+2$ & 279 & $1.42 \%$ & $1.75 \%$ & 0.0674 & 0.0337 \\
\hline & $t+3$ & 267 & $2.64 \%$ & $3.55 \%$ & 0.0022 & 0.0010 \\
\hline \multirow{4}{*}{ Change in total debt ratio (if positive in $t$ ) } & $\mathrm{t}$ & 153 & $8.16 \%$ & $6.52 \%$ & 0.0000 & 0.0000 \\
\hline & $\mathrm{t}+1$ & 154 & $7.66 \%$ & $6.35 \%$ & 0.0000 & 0.0000 \\
\hline & $t+2$ & 150 & $6.72 \%$ & $8.64 \%$ & 0.0000 & 0.0000 \\
\hline & $\mathrm{t}+3$ & 144 & $8.18 \%$ & $10.19 \%$ & 0.0000 & 0.0000 \\
\hline \multirow{3}{*}{ Change in long-term debt ratio } & $\mathrm{t}$ & 290 & $2.28 \%$ & $0.56 \%$ & 0.0000 & 0.0000 \\
\hline & $\mathrm{t}+1$ & 288 & $2.78 \%$ & $1.95 \%$ & 0.0000 & 0.0000 \\
\hline & $t+2$ & 279 & $2.80 \%$ & $1.57 \%$ & 0.0000 & 0.0000 \\
\hline
\end{tabular}




\begin{tabular}{ccccccc} 
& $\mathrm{t}+3$ & 267 & $3.25 \%$ & $3.37 \%$ & $\mathbf{0 . 0 0 0 0}$ & $\boldsymbol{0 . 0 0 0 0}$ \\
& & & & & & \\
Change in long-term debt ratio (if positive & $\mathrm{t}$ & 161 & $6.97 \%$ & $6.09 \%$ & $\mathbf{0 . 0 0 0 0}$ & $\boldsymbol{0 . 0 0 0 0}$ \\
in t) & $\mathrm{t}+1$ & 161 & $7.00 \%$ & $6.60 \%$ & $\mathbf{0 . 0 0 0 0}$ & $\boldsymbol{0 . 0 0 0 0}$ \\
& $\mathrm{t}+2$ & 157 & $6.14 \%$ & $6.19 \%$ & $\boldsymbol{0 . 0 0 0 0}$ & $\boldsymbol{0 . 0 0 0 0}$ \\
& $\mathrm{t}+3$ & 148 & $6.02 \%$ & $6.64 \%$ & $\mathbf{0 . 0 0 0 0}$ & $\boldsymbol{0 . 0 0 0 0}$ \\
\hline
\end{tabular}

Description: This table reports summary statistics on the change in the ratio of (long-term) debt to total assets; it reports these same summary statistics for the subsample of leverage-increasing transactions.

Next, we examine the correlations between our different measures of M\&A value creation. Table 10 reveals that the bidder CAR is not significantly associated with revenue-enhancement synergies. Sales growth by itself thus does not seem to bear a strong relation with M\&A value creation as perceived by stock market investors. Yet, we do find some evidence of a weak positive relation of the bidder CAR with cost-based synergies as well as with investment-based synergies, particularly net working capital. Lastly, we document a significant positive correlation between the bidder CAR and financial synergies. Arguably, the above results allow us to conclude that stock market investors are able to impound $\mathrm{M} \& \mathrm{~A}$ synergistic gains at deal announcement.

Table 10. Correlations between various synergy measures

\begin{tabular}{|c|c|c|c|c|c|c|}
\hline & $\begin{array}{r}\text { Bidder } \\
\text { CAR }[-20,+1]\end{array}$ & $\begin{array}{r}\text { Abnormal } \\
\text { change in } \\
\text { sales }\end{array}$ & $\begin{array}{c}\text { Abnormal } \\
\text { change in } \\
\text { operating } \\
\text { costs/sales }\end{array}$ & $\begin{array}{r}\text { Abnormal } \\
\text { change in net } \\
\text { working } \\
\text { capital }\end{array}$ & $\begin{array}{r}\text { Abnormal } \\
\text { change in } \\
\text { tangible } \\
\text { fixed assets }\end{array}$ & $\begin{array}{r}\text { Change in } \\
\text { long-term } \\
\text { debt/assets }\end{array}$ \\
\hline Bidder & 1.0000 & & & & & \\
\hline $\begin{array}{r}C A R[-20,+1] \\
\text { Abnormal change } \\
\text { in sales }\end{array}$ & $\begin{array}{r}-0.0140 \\
(0.8355)\end{array}$ & 1.0000 & & & & \\
\hline $\begin{array}{r}\text { Abnormal change } \\
\text { in operating } \\
\text { costs/sales }\end{array}$ & $\begin{array}{r}-0.0842 \\
(0.1113)\end{array}$ & $\begin{array}{r}-0.2032 \\
(0.0007)\end{array}$ & 1.0000 & & & \\
\hline $\begin{array}{r}\text { Abnormal change } \\
\text { in net working } \\
\text { capital }\end{array}$ & $\begin{array}{r}-0.1429 \\
(0.0410)\end{array}$ & $\begin{array}{r}-0.1454 \\
(0.0204)\end{array}$ & $\begin{array}{r}0.0279 \\
(0.6579)\end{array}$ & 1.0000 & & \\
\hline $\begin{array}{r}\text { Abnormal change } \\
\text { in tangible fixed } \\
\text { assets }\end{array}$ & $\begin{array}{r}0.0092 \\
(0.8954)\end{array}$ & $\begin{array}{r}-0.1351 \\
(0.0304)\end{array}$ & $\begin{array}{r}0.0347 \\
(0.5801)\end{array}$ & $\begin{array}{r}0.4339 \\
(0.0000)\end{array}$ & 1.0000 & \\
\hline $\begin{array}{l}\text { Change in } \\
\text { long-term } \\
\text { debt/assets }\end{array}$ & $\begin{array}{r}0.1339 \\
(0.0415)\end{array}$ & $\begin{array}{r}-0.0843 \\
(0.1635)\end{array}$ & $\begin{array}{r}-0.0802 \\
(0.1826)\end{array}$ & $\begin{array}{r}0.0591 \\
(0.3512)\end{array}$ & $\begin{array}{r}0.0611 \\
(0.3319)\end{array}$ & 1.0000 \\
\hline
\end{tabular}

Description: This table reports the pairwise correlation coefficients between the bidder CAR, the proxies for operating synergies in the second post-M\&A year, as well as the measure of financial synergies in the M\&A year.

When considering the correlations among the different types of operating synergies, we note that the combined firms that accomplish substantial revenue-enhancement synergies also achieve large cost-based and investment-based synergies, in net working capital as well as in tangible fixed assets. This result likely reflects that economies of scale are easier to achieve when firms are able to expand their sales volume following the acquisition. Next, we find a significant positive correlation between our two measures of investment-based synergies. Finally, Table 10 reveals that operating synergies and financial synergies are not necessarily related.

\subsection{Determinants of Synergy Realization}

After having established the magnitude and the timing of operating and financial synergies for our sample of non-serial acquirers in Europe, we investigate what deal and bidder characteristics influence the size of those sources of M\&A value creation. To that end, we rely on the existing literature to identify the characteristics that typically bear an effect on the post-M\&A stock and/or accounting performance of acquiring companies (Rau and Vermaelen, 1998; Harford, 1999; Moeller et al., 2004; Martynova and Renneboog, 2008; Craninckx and Huyghebaert, 2011). So, we examine the effects of industry relatedness, geographical overlap, deal-payment method (a dummy equal to one when the acquisition was fully paid in stock), and a dummy capturing whether the target firm is publicly listed. Next, 
we add relative target size, which is calculated as the target's sales revenues divided by the bidder's, given that many target firms in our sample are not listed. Besides, we explore the effects of the acquirer's debt ratio, market-to-book ratio of equity, and firm size (measured by the log of bidder market capitalization). Finally, we add a dummy variable to control for the fact that a large fraction of acquirers are located in the UK. To limit the influence of outliers, we winsorize all explanatory variables at 5-95\%, that is extreme values are replaced by the corresponding percentiles. Inspection of pairwise correlations and variance inflation factors (VIF) did not suggest any multicollinearity problems.

Table 11 reports the output of a number of OLS regression models, explaining the size of M\&A synergies. We first analyze the determinants of the bidder CAR in the window $[-20,+1]$. We thereafter examine the determinants of operating synergies, which are proxied by the benchmark-adjusted change in sales growth, operating costs/sales, net working capital/sales, and tangible fixed assets/sales, respectively by the second post-M\&A year. Our analyses in Tables 5-8 revealed that operating synergies are already largely accomplished by the second post-M\&A year. Moreover, using the data from the second rather than the third post-deal year allows us to rely on a larger sample to run the regressions. Finally, we investigate the determinants of financial synergies, as captured by the change in the long-term debt ratio in the year of acquisition, as financial synergies arise instantaneously (Table 9). Nonetheless, we check the robustness of our results when using other windows for the different sources of M\&A value creation.

Table 11. Determinants of synergy realization

\begin{tabular}{|c|c|c|c|c|c|c|}
\hline & \multirow{2}{*}{$\begin{array}{c}\text { Bidder } \boldsymbol{C A R} \\
\text { CAR }[-20,+1]\end{array}$} & \multicolumn{4}{|c|}{ Operating Synergies } & \multirow{2}{*}{$\begin{array}{c}\begin{array}{c}\text { Financial } \\
\text { synergies }\end{array} \\
\text { Change in } \\
\text { long-term } \\
\text { debt/assets }\end{array}$} \\
\hline & & $\begin{array}{l}\text { Abnormal } \\
\text { change in } \\
\text { sales }\end{array}$ & $\begin{array}{l}\text { Abnormal } \\
\text { change in } \\
\text { operating } \\
\text { costs/sales }\end{array}$ & $\begin{array}{c}\text { Abnormal } \\
\text { change in net } \\
\text { working } \\
\text { capital }\end{array}$ & $\begin{array}{c}\text { Abnormal } \\
\text { change in } \\
\text { tangible fixed } \\
\text { assets }\end{array}$ & \\
\hline $\mathrm{C}$ & $\begin{array}{r}0.1314 \\
(0.0161)\end{array}$ & $\begin{array}{r}0.4368 \\
(0.1002)\end{array}$ & $\begin{array}{r}-0.0615 \\
(0.1113)\end{array}$ & $\begin{array}{r}0.0959 \\
(0.2135)\end{array}$ & $\begin{array}{r}0.0231 \\
(0.5815)\end{array}$ & $\begin{array}{r}0.0629 \\
(0.1433)\end{array}$ \\
\hline $\begin{array}{l}\text { Industry- } \\
\text { diversifying deal }\end{array}$ & $\begin{array}{c}-0.0292 \\
(0.0380)\end{array}$ & $\begin{array}{l}-0.0663 \\
(0.3482)\end{array}$ & $\begin{array}{r}-0.0097 \\
(0.3130)\end{array}$ & $\begin{array}{r}0.0001 \\
(0.9977)\end{array}$ & $\begin{array}{l}-0.0014 \\
(0.9193)\end{array}$ & $\begin{array}{r}0.0005 \\
(0.9726)\end{array}$ \\
\hline Cross-border deal & $\begin{array}{r}0.0008 \\
(0.9582)\end{array}$ & $\begin{array}{r}0.0633 \\
(0.4197)\end{array}$ & $\begin{array}{r}-0.0201 \\
(0.0728)\end{array}$ & $\begin{array}{r}0.0032 \\
(0.8945)\end{array}$ & $\begin{array}{r}-0.0108 \\
(0.4345)\end{array}$ & $\begin{array}{r}-0.0025 \\
(0.8807)\end{array}$ \\
\hline $\begin{array}{l}\text { Full-stock } \\
\text { dummy }\end{array}$ & $\begin{array}{r}-0.0346 \\
(0.1054)\end{array}$ & $\begin{array}{r}0.1162 \\
(0.3917)\end{array}$ & $\begin{array}{r}0.0045 \\
(0.8271)\end{array}$ & $\begin{array}{r}0.0051 \\
(0.8942)\end{array}$ & $\begin{array}{r}-0.0233 \\
(0.2695)\end{array}$ & $\begin{array}{r}-0.0626 \\
(0.0011)\end{array}$ \\
\hline $\begin{array}{l}\text { Quoted-target } \\
\text { dummy }\end{array}$ & $\begin{array}{r}0.0083 \\
(0.7522)\end{array}$ & $\begin{array}{l}-0.0327 \\
(0.8827)\end{array}$ & $\begin{array}{c}-0.0308 \\
(0.4146)\end{array}$ & $\begin{array}{r}0.0372 \\
(0.5621)\end{array}$ & $\begin{array}{l}-0.0196 \\
(0.5292)\end{array}$ & $\begin{array}{r}0.0500 \\
(0.0550)\end{array}$ \\
\hline $\begin{array}{l}\text { Target } \\
\text { sales/bidder sales }\end{array}$ & $\begin{array}{r}0.0261 \\
(0.3117)\end{array}$ & $\begin{array}{l}-0.0110 \\
(0.9239)\end{array}$ & $\begin{array}{r}0.0030 \\
(0.8495)\end{array}$ & $\begin{array}{r}-0.0251 \\
(0.4109)\end{array}$ & $\begin{array}{r}0.0375 \\
(0.0393)\end{array}$ & $\begin{array}{r}-0.0274 \\
(0.1693)\end{array}$ \\
\hline Bidder leverage & $\begin{array}{r}0.0604 \\
(0.1562)\end{array}$ & $\begin{array}{r}-0.1447 \\
(0.5142)\end{array}$ & $\begin{array}{r}-0.0073 \\
(0.8340)\end{array}$ & $\begin{array}{r}-0.0395 \\
(0.5698)\end{array}$ & $\begin{array}{r}-0.0483 \\
(0.1876)\end{array}$ & $\begin{array}{r}-0.0074 \\
(0.8576)\end{array}$ \\
\hline $\begin{array}{l}\text { Bidder } \\
\text { market-to-book }\end{array}$ & $\begin{array}{r}0.0020 \\
(0.5848)\end{array}$ & $\begin{array}{r}0.0408 \\
(0.0108)\end{array}$ & $\begin{array}{r}-0.0055 \\
(0.0213)\end{array}$ & $\begin{array}{r}-0.0090 \\
(0.0463)\end{array}$ & $\begin{array}{r}-0.0071 \\
(0.0034)\end{array}$ & $\begin{array}{r}0.0040 \\
(0.2078)\end{array}$ \\
\hline $\begin{array}{l}\text { Ln(Bidder market } \\
\text { cap) }\end{array}$ & $\begin{array}{r}-0.0101 \\
(0.0047)\end{array}$ & $\begin{array}{r}-0.0326 \\
(0.1416)\end{array}$ & $\begin{array}{r}0.0057 \\
(\mathbf{0 . 0 8 8 3})\end{array}$ & $\begin{array}{r}-0.0020 \\
(0.7364)\end{array}$ & $\begin{array}{r}0.0033 \\
(0.2962)\end{array}$ & $\begin{array}{r}-0.0030 \\
(0.3641)\end{array}$ \\
\hline UK bidder & $\begin{array}{r}-0.0002 \\
(0.9912) \\
\end{array}$ & $\begin{array}{r}-0.0141 \\
(0.8365) \\
\end{array}$ & $\begin{array}{r}0.0048 \\
(0.6140)\end{array}$ & $\begin{array}{r}\mathbf{- 0 . 0 3 6 7} \\
(\mathbf{0 . 0 7 9 1 )} \\
\end{array}$ & $\begin{array}{r}-\mathbf{0 . 0 2 6 8} \\
(\mathbf{0 . 0 2 3 8 )} \\
\end{array}$ & $\begin{array}{r}0.0050 \\
(0.6829) \\
\end{array}$ \\
\hline $\begin{array}{l}\text { N } \\
\text { R-square } \\
\text { Adjusted }\end{array}$ & $\begin{array}{r}150 \\
0.1050\end{array}$ & $\begin{array}{r}141 \\
0.0857\end{array}$ & $\begin{array}{r}141 \\
0.0912\end{array}$ & $\begin{array}{r}129 \\
0.0701\end{array}$ & $\begin{array}{r}130 \\
0.1437\end{array}$ & $\begin{array}{r}147 \\
0.0872\end{array}$ \\
\hline R-square & 0.0475 & 0.0229 & 0.0287 & -0.0002 & 0.0795 & 0.0272 \\
\hline
\end{tabular}


Description: This table reports OLS regressions results where the dependent variable equals the bidder CAR over the window starting 20 days before deal announcement until 1 day thereafter, the proxies for operating synergies in the second post-M\&A year, as well as the measure of financial synergies in the year of the transaction. The explanatory variables in these regression models are: an industry-diversifying dummy equal to one when the bidder and target have a different main four-digit SIC industry code, a cross-border dummy equal to one when the bidder and target have their headquarters in a different country, a full-stock dummy that equals one when the deal is entirely paid for with stock, a quoted-target dummy equal to one if the target is listed on a stock exchange, the ratio of the target's total sales divided by the bidder's, the bidder's total debt relative to total assets, the bidder market-to-book ratio of equity, the natural $\log$ of the bidder market capitalization, and a UK-bidder dummy that equals one if the bidder is located in the UK. The bidder characteristics are measured in the year before the transaction. All models control for time clustering of the M\&As in the sample. $p$-values are calculated using White heteroscedasticity-consistent standard errors and are reported between parentheses.

The results in the first column of Table 11 provide evidence on the determinants of the bidder CAR. Overall, our findings are in line with prior research, documenting a lower bidder abnormal return for industry-diversifying deals and for fully stock-paid acquisitions. Yet, the latter variable is only marginally significant ( $p$-value of 0.1054$)$. In line with the literature, a lower bidder CAR for deals that are fully compensated by means of bidder stock may suggest that a negative signal is sent to stock market investors about the value of the acquirer stock in those transactions. Alternatively, the lower bidder CAR could also be reflecting the lower financial synergies in fully stock-paid acquisitions (see infra). Also in line with previous research (e.g., Moeller et al., 2004; Bouwman et al., 2009), we find that the bidder abnormal return around deal announcement is significantly smaller for large bidders.

Table 11, columns $2-5$ present our results on the determinants of the different sources of operating synergies. The regression output reveals that the dummy capturing the industry relatedness of the deal is never significant in explaining the magnitude of operating synergies. This conclusion also emerges when defining industry relatedness at the two-digit instead of the four-digit SIC level (not reported). So, the consolidation of operations of two industry rivals is unlikely to explain the divergence in operating synergies across sample firms. The negative coefficient on industry relatedness in the bidder CAR regressions can therefore not be attributed to smaller operating synergies in those transactions. As an example, stock market investors may also account for changes in the level of industry competition arising from the deal, thereby affecting the value of the combined firm (see Huyghebaert and Luypaert, 2013). Next, the geographical dimension of the deal only bears an effect on cost-based synergies. Specifically, we find that post-M\&A operating costs are significantly smaller in cross-border acquisitions, thereby suggesting that those takeovers are not the first entry of the bidder into the foreign market. Indeed, in order to be able to accomplish economies of scale and/or economies of scope in operating costs, the target firm should be physically integrated with another business. Unfortunately, our dataset does not allow us to further investigate this idea. As to the method of deal payment and the dummy capturing a publicly listed target firm, we find no significant association with the magnitude of operating synergies.

Next, the results in Table 11 clearly point out that operating synergies are larger when the acquirer has a higher market-to-book ratio. Specifically, takeovers initiated by highly valued acquirers result in larger post-M\&A sales growth rates, lower operating costs, and lower investments in net working capital and tangible fixed assets. Those results thus indicate that highly valued acquirers are successful in reorganizing target firms so as to increase their sales potential, to reduce their operating expenses, and to use their assets more efficiently. However, they contrast with the conventional wisdom that managers in firms with a high market-to-book ratio, popularly known as glamour firms, are more likely to be infected by overconfidence and hubris. Those managers then tend to over-extrapolate the past performance of their firm when initiating acquisitions, thereby engaging in lower-value deals (e.g., Roll, 1986; Rau and Vermaelen, 1998). Yet, given the focus of our study on non-serial acquirers, our findings may not be that surprising after all. For the latter firms, who do not seem to take advantage of transient windows of opportunity by engaging in multiple acquisitions when stock prices are soaring, a large market-to-book ratio could be a better indication of the firm's valuable management and growth prospects.

Table 11 further reveals that the size of the acquiring company positively influences the post-M\&A ratio of operating expenses to sales. The latter finding may provide some interesting insights into why so many studies, including ours, have found a negative effect of the bidder's size on the bidder CAR (see also Moeller et al., 2004, Bouwman et al., 2009). Table 11 indeed suggests that large acquirers find it more difficult to integrate the target business in a cost-efficient manner. Likewise, acquisitions of relatively large target firms are less likely to engender savings in the use of tangible fixed assets. Finally, the results provide some indication that the abnormal changes in net working 
capital as well as in tangible fixed assets are smaller when the acquirer is headquartered in the UK. So, in line with Devos et al. (2009), companies in an Anglo-Saxon context are able to achieve larger investment-based synergies.

Finally, the last column in Table 11 displays our findings on the determinants of financial synergies. Most importantly, we find no evidence whatsoever that diversification - either industry or geographical - influences the magnitude of financial synergies. Next, as already pointed out, stock-paid acquisitions result in a smaller increase in the post-M\&A debt ratio. Conversely, the increase in the long-term debt ratio is larger when the acquisition involves a publicly listed target firm. A more detailed examination of target leverage before the M\&A reveals that listed target firms have an average long-term debt ratio of only $30.60 \%$ (sample average of $42.10 \%$ ), indicating highly unused debt capacity.

Overall, the results in Table 11 clearly point out that the bidder CAR, which is used to proxy for expected M\&A value creation, and our various measures of realized M\&A synergies are not always influenced by the same variables. One explanation could be that the shareholders in the acquiring companies not only consider the magnitude of expected operating and financial synergies, but also account for the price that is being paid for target control (see, for example, Hietala et al., 2003). However, prior research has found that the combined CAR and the bidder CAR are typically positively correlated (e.g., Wang and Xie, 2009). In our sample of non-serial acquirers, we also noted such a positive correlation. So, the size of the acquisition premium is unlikely to explain the deviation in results for the bidder CAR and our measures of operating and financial synergies. Another possible explanation is that the stock price of the acquiring company not only adjusts to information about the value of synergies, but also to information about the acquirer's intrinsic value by choosing a particular takeover target, deal structure, etc. In sum, while the bidder CAR is clearly related to the actual realization of operating and financial synergies, as shown in Table 10, it also captures other forces that are not necessarily related to M\&A synergies. Then, it is not surprising to find that the determinants of the acquirer CAR and the determinants of operating and financial synergies do not always largely overlap.

\subsection{Robustness Checks}

In order to assess the robustness of our findings, we perform several sensitivity checks (not reported). We first examine the robustness of our findings in other event windows. We conclude that the determinants of the bidder CAR remain unchanged for smaller (e.g., $[-5,+1])$ as well as longer event windows (e.g., $[-50,+1])$. Also, calculating operating and financial synergies over other post-M\&A windows does not materially affect our main inferences. Next, we examine what happens once we add a number of extra control variables, such as the bidder ROA, cash ratio, ownership concentration, and toehold. Also, following Wang and Xie (2009), we include a dummy variable capturing M\&As between high-tech companies. We find that these variables are neither significantly related to the bidder CAR nor to operating or financial synergies. More importantly, including those extra variables does not affect our main results.

Given the significance of the dummy capturing deals by UK bidders in the regression models explaining investment-based synergies, we investigate whether our conclusions generalize once models are separately estimated for M\&As initiated by Continental European bidders and for M\&As initiated by UK bidders. We find that while the impact of the bidder market-to-book ratio is significantly negative in both subsamples, the effect of target relative size is only significant in the UK subsample. Next, we also check for clustering at the country level by adding extra country dummies; this does not affect our main findings.

Finally, we control for clustering over time by including year dummies. In addition, we examine the subsample of deals completed between 1997 and 2004, given that 44.03\% of sample deals took place in 2005. We again find that our earlier conclusions remain valid, allowing us to conclude that our results are not driven by one sample year.

\section{Conclusions}

In this paper, we empirically investigate the magnitude and the timing of synergy realization for a sample of 293 M\&As by non-serial acquirers in the European Union during 1997-2005. For this purpose, we calculate direct measures of operating synergies as well as financial synergies, based upon the financial statements of the combining companies and their non-combining industry peers before and after deal completion.

In contrast to much of the existing literature, our results clearly demonstrate that acquisitions by non-frequent acquirers are value-enhancing events for shareholders in the bidding company. On average, those investors earn an abnormal return of $2.68 \%$ over the period starting 20 days before deal announcement until one day thereafter. While previous studies investigating the sources of M\&A value creation in the USA - using either case surveys or forecasts from managers and financial analysts - report that operating synergies are driven by cutbacks in investment 
expenditures, the results in this article clearly show that revenue-enhancement synergies and cost-based synergies are highly important for non-serial acquirers in Europe as of the mid-1990s. In particular, we find that the sales growth rates of the newly combined firms are considerably larger than expected by the third post-M\&A year, with the median abnormal increase being equal to $4.92 \%$. Furthermore, cost-based synergies are achieved as of the acquisition year. The latter finding indicates that the combining companies in our sample succeed in integrating their businesses quickly. The median extra decrease in operating costs relative to sales equals $1.53 \%$ by the third year following deal completion. Overall, and in contrast to the evidence from the leveraged M\&A wave of the 1980s, our results do not support the idea that cutbacks in investment expenditures are an important source of operating synergies. Finally, we show that the takeovers in our sample have a significant positive effect on the fraction of assets being financed by means of long-term debt, leading to lower post-M\&A tax rates while having no immediate impact on the cost of debt.

Regarding the determinants of the magnitude of these sources of operating and financial synergies, we identify several influential deal and bidder characteristics. First, the acquirer's pre-M\&A market-to-book ratio has a significant positive effect on the magnitude of all types of operating synergies. Next, we show that the size of cost-based synergies is larger in cross-border M\&As, while being negatively affected by the size of the bidding company. Also, acquisitions of relatively large target firms are less likely to engender savings in the use of tangible fixed assets. Our results further reveal that the magnitude of investment-based synergies is lower in deals initiated by the UK bidders in our sample. Concerning financial synergies, we report a larger increase in the long-term debt ratio of newly combined firms after cash-paid acquisitions and takeovers of publicly listed target firms.

Arguably, our more positive conclusions on the bidder CAR and M\&A synergies compared to prior research likely is related to differences in sample characteristics. Specifically, we focus on a sample of takeovers initiated by non-frequent acquirers, which tend to outperform serial acquirers. Furthermore, while the bulk of the M\&A literature has focused on Anglo-Saxon transactions in the 1980s wave, we examine acquisitions as of the mid-1990s, being characterized by strategic rationales. Also, the lower incidence of stock offers in Europe limits the role of stock market misvaluation as an external growth motive. Finally, the more concentrated ownership structure of firms in Continental Europe is likely to reduce the impact of managerial self-serving behavior as an antecedent of acquisitions.

\section{Acknowledgements}

The authors thank Nihat Aktas, Katrien Craninckx, Wouter De Maeseneire, Stefan Duchateau, Sophie Manigart, Urs Peyer, Randy Priem, Filip Roodhooft, Cynthia Van Hulle, Lihong Wang, Burcin Yurtoglu, and participants in the Corporate Finance Day (September 2009, Antwerp), the EIASM workshop on cross-border M\&A (November 2009, Brussels) and seminars at Ghent University and K.U. Leuven for useful comments on an earlier draft of this paper. Also, the authors wish to sincerely thank the National Bank of Belgium (NB/07/04) for the financial support that was received for this research project.

\section{References}

Agrawal, A., Jaffe, J.F., \& Mandelker, G.N. (1992). The post-merger performance of acquiring firms. A re-examination of an anomaly. Journal of Finance, 47, 1605-1621. http://dx.doi.org/10.1111/j.1540-6261.1992.tb04674.x

Aktas, N., de Bodt, E., \& Roll, R. (2011). Serial acquirer bidding: An empirical test of the learning hypothesis. Journal of Corporate Finance, 17, 18-32. http://dx.doi.org/10.1016/j.jcorpfin.2010.07.002

Andrade, G., Mitchell, M., \& Stafford, E. (2001). New evidence and perspectives on mergers. Journal of Economic Perspectives, 15, 103-120. http://dx.doi.org/10.1257/jep.15.2.103

Barber, B.M., \& Lyon, J.D. (1997). Detecting long-run abnormal stock returns: The empirical power and specification of test statistics. Journal of Financial Economics, 43, 341-372. http://dx.doi.org/10.1016/S0304-405X(96)00890-2

Billet, M.T., \& Qian, Y. (2008). Are overconfident managers born or made? Evidence of self-attribution bias from frequent acquirers. Management Science, 54, 1037-1051. http://dx.doi.org/10.1287/mnsc. 1070.0830

Bouwman C., Fuller, K., \& Nain, A. (2009). Market valuation and acquisition quality: Empirical evidence. Review of Financial Studies, 22, 633-679. http://dx.doi.org/10.1093/rfs/hhm073

Brown, S.J., \& Warner, J.B. (1985). Using daily stock returns: The case of event studies. Journal of Financial Economics, 14, 3-31. http://dx.doi.org/10.1016/0304-405X(85)90042-X 
Capron, L. (1999). The long run performance of horizontal acquisitions. Strategic Management Journal, 20, 987-1018. http://dx.doi.org/10.1002/(SICI)1097-0266(199911)20:11<987::AID-SMJ61>3.0.CO;2-B

Corrado, C.J. (1989). A non-parametric test for abnormal-security price performance in event studies. Journal of Financial Economics, 23, 385-395. http://dx.doi.org/10.1016/0304-405X(89)90064-0

Craninckx, K., \& Huyghebaert, N. (2011). Can stock markets predict M\&A failure? A study of European transactions in the fifth takeover wave. European Financial Management, 17, 9-45. http://dx.doi.org/10.1111/j.1468-036X.2010.00541.x

Devos, E., Kadapakkam, P.-R., \& Krishnamurthy, S. (2009). How do mergers create value? A comparison of taxes, market power, and efficiency improvements as explanations for synergies. Review of Financial Studies, 22, 1179-1211. http://dx.doi.org/10.1093/rfs/hhn019

Dickerson, A.P., Gibson, H.D., \& Tsakalotos, E. (1997). The impact of acquisitions on company performance: Evidence from a large panel of UK firms. Oxford Economic Papers, 49, 344-361. http://dx.doi.org/10.1093/oxfordjournals.oep.a028613

Dodd, P., \& Warner, J.B. (1983). On corporate governance: A study of proxy contests. Journal of Financial Economics, 11, 401-438. http://dx.doi.org/10.1016/0304-405X(83)90018-1

Draper, P., \& Paudyal, K. (2006). Acquisitions: Private versus Public. European Financial Management, 12, 57-80. http://dx.doi.org/10.1111/j.1354-7798.2006.00310.x

Ficery, K., Herd, T., \& Pursche, B. (2007). Where has all the synergy gone? The M\&A puzzle. Journal of Business Strategy, 28, 29-35. http://dx.doi.org/10.1108/02756660710820802

Gadiesh, O., Ormiston, C., \& Rovit, S. (2003). Achieving M\&As strategic goals at maximum speed for maximum value. Strategy and Leadership, 31, 35-41. http://dx.doi.org/10.1108/10878570310472746

Gaughan, P.A. (2002). Mergers, acquisitions, and corporate restructurings $\left(3^{\text {rd }}\right.$ ed.). New York, NY: John Wiley \& Sons.

Ghosh, A., \& Jain, P.C. (2000). Financial leverage changes associated with corporate mergers. Journal of Corporate Finance, 6, 377-402. http://dx.doi.org/10.1016/S0929-1199(00)00007-9

Gregory, A. (1997). An examination of the long-run performance of UK acquiring firms. Journal of Business Finance and Accounting, 24, 971-1002. http://dx.doi.org/10.1111/1468-5957.00146

Gugler, K., Mueller, D.C., Yurtoglu, B.B., \& Zulehner, C. (2003). The effects of mergers: An international comparison. International Journal of Industrial Organization, 21, 625-653. http://dx.doi.org/10.1016/S0167-7187(02)00107-8

Harford, J. (1999). Corporate cash reserves and acquisitions. Journal of Finance, 54, 1969-1997. http://dx.doi.org/10.1111/0022-1082.00179

Harford, J. (2005). What drives merger waves? Journal of Financial Economics, 77, 529-560. http://dx.doi.org/10.1016/j.jfineco.2004.05.004

Hietala, P., Kaplan, S.N., \& Robinson, D.T. (2003). What is the price of hubris? Using takeover battles to infer overpayments and synergies. Financial Management, 32, 5-31. http://dx.doi.org/10.2307/3666381

Houston, J.F., James, C.M., \& Ryngaert, M.D. (2001). Where do merger gains come from? Bank mergers from the perspective of insiders and outsiders. Journal of Financial Economics, 60, 285-331. http://dx.doi.org/10.1016/S0304-405X(01)00046-0

Huyghebaert, N., \& Luypaert, M. (2010). Antecedents of growth through mergers and acquisitions: Empirical evidence from Belgium. Journal of Business Research, 63, 392-403. http://dx.doi.org/10.1016/j.jbusres.2009.06.003

Huyghebaert, N., \& Luypaert, M. (2013). Value creation and division of gains in horizontal acquisitions in Europe: The role of industry conditions. Applied Economics, 45, 1819-1833. http://dx.doi.org/10.1080/00036846.2011.639739

Ismail, A. (2008). Which acquirers gain more, single or multiple? Recent evidence from the USA market. Global Finance Journal, 19, 72-84. http://dx.doi.org/10.1016/j.gfj.2008.01.002

Laamanen, Y., \& Keil, T. (2008). Performance of serial acquirers: toward an acquisition program perspective. Strategic Management Journal, 29, 663-672. http://dx.doi.org/10.1002/smj.670 
Larsson, R., \& Finkelstein, S. (1999). Integrating strategic, organizational and human resource perspectives on mergers and acquisitions: A case survey of synergy realization. Organization Science, 10, 1-26. http://dx.doi.org/10.1287/orsc.10.1.1

Martynova, M., \& Renneboog, L. (2008). A century of corporate takeovers: What have we learned and where do we stand? Journal of Banking and Finance, 32, 2148-2177. http://dx.doi.org/10.1016/j.jbankfin.2007.12.038

McGuckin, R., \& Nguyen, S. (2001). The impact of ownership changes: A view from labor markets. International Journal of Industrial Organization, 19, 739-762. http://dx.doi.org/10.1016/S0167-7187(00)00092-8

Moeller, S.B., Schlingemann, F.P., \& Stulz, R.M. (2004). Firm size and the gains from acquisitions, Journal of Financial Economics, 73, 201-228. http://dx.doi.org/10.1016/j.jfineco.2003.07.002

Mukherjee, T.K., Kiymaz, H., \& Baker, H.K. (2004). Merger motives and target valuation: A survey of evidence from CFOs. Journal of Applied Finance, 14, 7-24.

Rau, R., \& Vermaelen, T. (1998). Glamour, value and the post-acquisition performance of acquiring firms. Journal of Financial Economics, 49, 223-253. http://dx.doi.org/10.1016/S0304-405X(98)00023-3

Ravenscraft, D.J., \& Scherer, M. (1987). Life after takeover. Journal of Industrial Economics, 36, 147-156. http://dx.doi.org/10.2307/2098409

Roll, R. (1986). The hubris hypothesis of corporate takeovers. Journal of Business, 59, 197-216. http://dx.doi.org/10.1086/296325

Scholes, M., \& Williams, J.T. (1977). Estimating betas from nonsynchronous data. Journal of Financial Economics, 5, 309-327. http://dx.doi.org/10.1016/0304-405X(77)90041-1

Wang, C., \& Xie, F. (2009). Corporate governance transfer and synergistic gains from mergers and acquisitions. Review of Financial Studies, 22, 829-858. http://dx.doi.org/10.1093/rfs/hhn018

\section{Notes}

Note 1. Larsson and Finkelstein (1999), for example, conduct a survey for 61 M\&As completed during 1959-1989 in the USA and in Europe and illustrate that the combination potential of the deal (measured by similarities and complementarities in the production and marketing operations of combining firms), organizational integration (proxied by the use of coordinating mechanisms during the integration period), and employee resistance to the takeover all determine the magnitude of actual synergies. Next, Capron (1999) surveys acquiring managers in 253 horizontal US and European M\&As from 1988 to 1992. Her results reveal that both resource redeployment and asset divestitures are important drivers of M\&A synergies. Likewise, Houston et al. (2001) decide on synergy gains in 41 large bank mergers, using management estimates of revenue enhancement and cost savings. They document average gains of about $13 \%$, arising from cost savings rather than revenue enhancement.

Note 2. The Zephyr database is commercialized by Bureau van Dijk and contains detailed information on more than half a million M\&As worldwide, with pan-European deals dating back to 1997 and North American deals included as of 2001. M\&As involving public as well as private bidders are covered and there is no minimum deal value in order for a deal to be included in the database. Compared to the SDC Platinum database of Thomson Financial and Mergerstat, the Zephyr database has a better coverage of European mergers and acquisitions.

Note 3. The Amadeus database, also commercialized by Bureau van Dijk, is a comprehensive pan-European database containing accounting data for more than 11 million public and private enterprises in 41 countries. There are no specific size requirements for a firm to be included in the database.

Note 4 . The divestment of previously acquired companies could bias our results, as the assets, liabilities, revenues, and costs of these target firms are no longer included in the consolidated financial statements of the bidder as of the divestment. We therefore only include these acquirers in our analyses until the year of actual divestment. Using the Zephyr database, we checked potential divestments of target firms in the three years following deal completion. We found that 7 targets $(2.39 \%$ of the sample) were divested, on average after 2.14 years (median of 2.00 years). Such low divestment numbers are not unusual for European M\&As in the fifth takeover wave (see, for example, Craninckx and Huyghebaert, 2011).

Note 5. Yet, information on the method of payment is known for only 202 out of 293 transactions, i.e. $68.94 \%$ of sample deals.

Note 6. The use of daily data could induce a bias in the OLS parameter estimates of the market model when some 
securities are only infrequently traded. Hence, we apply the Scholes-Williams (1977) procedure to derive consistent estimators for the market model parameters.

Note 7. Return data were downloaded from Datastream and are available for 233 out of 293 transactions (i.e. $79.52 \%$ of sample deals).

Note 8. If no matching firm could be identified at the four-digit SIC level, a potential benchmark at the three- (or two-)digit SIC level was identified. 39 bidders and 29 targets had to be matched based upon three-digit SIC codes, while 28 bidders and 9 targets had to be matched based upon two-digit SIC codes.

Note 9. The average (median) difference in EBITDA/sales between sample and matching firms equals a non-significant $0.16 \%(0.09 \%)$ for bidders and $-1.81 \%(-0.05 \%)$ for takeover targets.

Note 10. The sample size diminishes as extra years after M\&A completion are examined. First, transactions for which the target firm was divested within three years after deal completion are included in the analyses only until the year of actual divestment. The Zephyr database allowed us to identify 7 target firms that were divested within this three-year time frame. Besides, a number of combined firms may no longer be included in the Amadeus database over time, because of their bankruptcy or acquisition. As only 10 combined firms in the sample ended their operations as a separate legal entity within the studied time window, we consider the impact of survival bias on our empirical findings to be limited. Nonetheless, to further explore whether a potential survival bias could influence some of our inferences, we also calculated our various measures of operating and financial synergies for the subsample of combined firms that could be followed during a three-year window, concluding that this did not hugely affect our results.

Note 11. A direct investigation of effective tax rates (=Taxes/Earnings before taxes) revealed that the additional debt results in significantly lower tax rates in the years following the acquisition. The average (median) reduction in the tax rate equals $3.69 \%(0.54 \%)$. We also considered the impact of the takeover on the cost of debt, computed as the change in the yield spread from before to after the acquisition. We find that the average (median) change in the cost of debt equals an insignificant $-0.38 \%(0.41 \%)$ in the year of takeover. When limiting this analysis to leverage-increasing acquisitions, the change in the yield spread is still not significant. Taken together, these results thus clearly point out that the newly combined firms succeed in financing a larger part of their activities with long-term debt, increasing the debt tax shield, without adversely affecting the cost of debt. 